\title{
Education in Malaysia: Educating for Inclusive-Holistic Growth, Political Needs...?-The Transformation of Vernacular and Particularised Education towards Integration into "Malaysian Education"
}

\author{
Suranthiran Naidu M. N. Naidu, Sivaperegasam Rajanthiran \\ College of Law, Government and International Studies, Universiti Utara Malaysia, Sintok, Malaysia \\ Email: inthal3317@gmail.com
}

How to cite this paper: Naidu, S. N. M. N., \& Rajanthiran, S. (2021). Education in Malaysia: Educating for Inclusive-Holistic Growth, Political Needs...?-The Transformation of Vernacular and Particularised Education towards Integration into "Malaysian Education". Open Journal of Social Sciences, 9, 471-490.

https://doi.org/10.4236/jss.2021.93031

Received: February 12, 2021

Accepted: March 28, 2021

Published: March 31, 2021

Copyright $\odot 2021$ by author(s) and Scientific Research Publishing Inc. This work is licensed under the Creative Commons Attribution International License (CC BY 4.0).

http://creativecommons.org/licenses/by/4.0/

\begin{abstract}
From the British colonial period and henceforth after independence, educationists have striven to unify the divided and "particularised" education structures that were taking firm roots in plural Malaya and thenceforth, Malaysia. The primary focus as boldly enshrined in the Malaysian Constitution, the national ideology statement-the Rukun Negara, the National Education Philosophy (NEP) and by the constant reminders and promptings of our founding fathers, was national integration of the ethnically and culturally diverse society. The aspiration of "sejahtera" (well-being) as propounded in the nation's NEP, seen together with the United Nations' SDGs (sustainable development goals), towards Education 2030, clearly points to the urgent need for further effort towards inclusive and quality education. The discussion on the prevalent, divided education system, attempting to answer the main research questions, centres on mother-tongue vernacular education and other sub-set education structures, such as the religious and "one-race" schools. These have inevitably with the course of decades, contributed to social disunity. It is found that educators emphasise that transformation and integration, and not the termination of these education sub-sets, into mainstream education, with a strong implementation of the national language and English in the school curriculum. This can help evolve Malaysian education into a globally reputed education system. Educationists are also of the view that it can be then an effective bonding tool for national unity. Language, religion, and literature subjects can be conducted in the mother-tongue languages within the ambit of the national education philosophy. In-depth one-to-one interviews of higher primary school learners, were found to have sparse knowledge in the Malay-
\end{abstract}


national language and English, in topical knowledge areas in Science, Moral Education, common knowledge concepts, and common civility greetings. Successful working models of education of certain plural societies towards national integration, provide constructive lessons for the constructive re-hauling of education in Malaysia.

\section{Keywords}

National Education, "Particularised" Education, Transformation, National Language, Education Models, Integration

\section{Introduction}

It is common knowledge today that the Malaysian education system is clearly multifarious. In common parlance it can be characterized as a divided education system.

The nation's demography is a vast mix of various ethnicities, a potpourri of culturally different people. Furnivall (1948) had described Malayan society as an entity made up of people that meet in the market place but do not mingle and interact as common citizens. It can be said from a general observation as well as from documented accounts that to a large extent the above observation stands true even to this day.

The question in the minds of concerned Malaysian parents, leaders, educators and "Rakyat" (Malaysian citizenry), is the predilection for and evolution of the nation towards a common Malaysian oneness-a "common nationality" [Government of Malaya (1951a) (Barnes Report)]. This, nevertheless, was essentially meant being a Malaysian nation and people, with their cultural-religious attributes allowed to be practised and flourish within one's communities.

What is most important and crucial for a forward-going Malaysian psyche is to learn to live and abide with this above cultural scenario, and not to allow one's particular beliefs to supersede and become superimposed on that of any community. It is a creation of the nationhood knowledge and value of full abidance and acceptance of one another as such, as within the requirements of the nation's constitution with regards Islam as the nation's official religion, the Malay language as the first official language, special privileges accorded to the MalayBumiputera community as indigenous people and natives of the land, and the position of the Malay rulers.

It is crucial and essential that the nation's school-youth and society is well "educated" in the knowledge that the Malaysian Federation, as from and before colonial occupation to the Malacca Sultanate in the sixteenth century and before, had evolved from the Malay Sultanates. Even Singapore had its genesis in the Johor-Riau Sultanate and the Malay Nusantara (Malay world in this part of the world).

With the continued reign of the Malay state sultans, and given their role as 
constitutional monarchs, the Constitution seeks to concretise the historical continuity of the identity of Malaysia (Federal Constitution 1957, 2010; Faruqi, 2012).

Further, the nation's Constitution places the Malay language as the national and the first official language of the nation. This is primarily because Malay mainly has deep cultural and historical roots and a strong relationship with the country and the entire region. It had and does continue to play the role of the medium of inter-ethnic communication amongst the larger pool of its masses. Thus, it can said that the Malay-Bahasa Melayu language-now referred to as "Bahasa Malaysia", has the innate constituent quality of possessing the nexus with the larger socio-cultural milieu of the land (Muzaffar, 2017: pp. 31-40).

It is NOT proposed in this paper that vernacular education be abolished ("tamatkan") in multicultural Malaysia. It can be noted at this juncture that more than $90 \%$ of Chinese parents and 50\% of Indian parents of primary-aged children prefer to put their children in Chinese and Tamil schools respectively (Yesuiah, 2020). This, being a large population of Malaysian parents as such, signifies and illustrates these parents' concern and aspirations to provide the best education possible for their children, as responsible and good parents naturally, and that of the general lament that national primary schools have declined in standards. It needs to be further noted that only a very small number of the personnel working in these schools can be reabsorbed into national schools or other public institutions, which are generally well-resourced, because of their "particularised" training and skills.

As such, this research paper is driven by the national goal of integrating the various parts of the nation's fractured education structure into a holistic scheme. It is undoubtedly an upheld aspiration in most societies that a common education system will gradualistically lay the foundations for a united, cohesive society. This should be one that truly stands up as the national, "mainstreaming" path of education for the young, and society. The long-established vernacular and pondok-agama-"tahfiz" education institutions ${ }^{1}$ need to be brought under the full ambit of the nation's education acts, the Federal Constitution, and be recognised as having a manifest place within the umbrella of the nation's ideological statement-the Rukun Negara, holistically. All these official documents emphasise strongly, in clear and unambiguous terms, that nation building and national unity, constitute the essential drivers of the nation's trajectory towards progress and a stable, sovereign nationhood.

\section{Research Objectives}

The primary and sole objective of this paper is to investigate the strains and ${ }^{1}$ As based on the htpps://simpeni.islam.gov.my "Portal Maklumat Pendidikan Islam", there are 4278 Islamic education schools ("Sekolah Agama") in Malaysia. As based on the "Quick Facts $2019 \mathrm{Ma}$ laysia Education” https://www.moe.gov.my/ website ISSN: 19856407 July 2019, there are more than 5872 national schools, with the majority of primary school-going students totaling 2,101,453 today. There were 1298 Chinese primary schools with 522,283 students. The earliest Chinese primary schools were set up as private home schools from as early as 1819 . Tamil vernacular education has celebrated more than 200 years of its existence in Malaysia. There are about 81,321 students in 525 Tamil primary schools as in 2019. 
threads in the Malaysian education system that can be transformed so that integrated education can evolve, towards cohesive nation-building and national integration.

\section{Research Questions}

1) What are the major constituents of the national education programme?

2) What are the shortcomings of the above in achieving national integration as professed by the nation's Federal Constitution and the nation's ideology statement, the Rukun Negara?

3) What can be appropriately and "rightly" attempted to bring about an encompassing and holistic "Malaysian" education system towards the goal of social solidarity of the Malaysia?

With the diverse societal groups predominantly, employing culturally-based language modes of instruction and learning, sociologically and psychologically it can be inevitable that pockets of the national society can become entrenched and become comfortably ensconced, with time, in their culturally differentiated lifeways and paths. This can be a consequence of the absence of any particular and diabolically designed ill-will against attaining a sense of national belonging by the diverse communities. Generally, as it has been demonstrated to this day, except for the tragic racial riots of 1969 referred to at times with dubious intentions, the observation of social science students generally is that, Malaysians want just to be "left to their own means", to live their lifes and be empowered appropriately with the servant-leadership of public officials, to strive to ensure the well-being of their lifes and that of their posterity, in peace and stability.

Often, it can be a "gradualising" development as an outgrowth from the inevitable sociological impacts-both negative and positive, as well as the ensuing relative social-political calm and stability, and entrenching attitudes attuned to ethnic-cultural traditions and values, practices and the acclaimed-often politically shouted about, "promises" of "safe" futures. It can be said at this juncture that the 1969 racial conflicts having made the strongest impact, and especially following that event, the dichotomizing Bumiputera-Malay and non-Bumiputera socially structured New Economic Policy (NEP), was launched. Although the latter was well-thought out with lofty goals for nation-building and economic progress, it led to a full throttle advancement of the majority, rural poor Malay, the "bumiputera"- "sons of the soil" community. The sociological ingredients to strengthen the crucial "drive" factors and the "character" of the NEP may not have been sufficiently infused and suffused-"educated" over the national psyche, particularly that of the benefitting communities (Mohamad, 2013: pp. 67-71; Majid, 2021: p. 23).

Thus, discrepancies and misconceptions have arisen, leading to the present day social phenomenon of pockets of culturally, closely grouped, divided communities. The people meet in the market place, in work, in school, live is residential places, but hardly interact, mingle, relate and "share" as one national society (Furnival, 1948). 
One essential and concretely cementing tool and force can be education, a well-ordered and vibrantly working institution truly tuned towards universal multicultural education. Allowing for the dominance of any one cultural-social variant can be negatively viewed as prejudiced and exclusive. Such a situation then will be unable to engender confidence for mutual acceptance as common citizens, from the other citizenry-cultural groups.

Possibly the enforcement of appropriately "strong" BUT equitable laws can bring about a semblance of "acceptance" to an inclusive and overarching nationalistic form introduced with the engagement of the major ethnic communities. All major cultural elements of the "living" communities in the social-national milieu then can "fit" in and be accorded their rightful places in the national polity. This then can well help evolve a sense of belonging, without the negative social sentiments of marginalization and subjugation.

When this above approach is directed at the multicultural youth untainted by political bigotry and a sense of communal superiority, as it is so often exhibited today, then the fertile and healthy seeds of communal bonding can be laid and germinated thenceforth, for unity and peace in the polity.

\section{Review of Related Literature}

\subsection{The National Education Acts}

Act 550 Education Act 1996 (2012), being the present law on education in force today, states that it is the duty of the Minister of education to ensure that primary education is provided in government and government-aided schools (Section 27). He is also required under Section 28 of this Act, to establish and maintain such schools.

Further, Section 17 (1) of the above Act states that “...the national language shall be the main medium of instruction in the National Education System except a national-type school established under Section 28 (as elaborated above)..." is exempted by the education Minister.

The national language shall be taught as a compulsory subject in the national-type (vernacular schools) education institution, if the main medium of instruction is other than the national language [clause 17(2)].

\subsection{The Federal Constitution and the Nation's National Ideology, the Rukun Negara}

The Federal Constitution and the national ideology statement-Rukun Negara, necessarily come into focus in the discussion of the position of vernacular education and its existential place in this pluralistic nation.

At the outset it can pointed out that the Constitution may appear as giving preferentiality all too much to the majority Malay-Bumiputera ("sons of the soil") community. Article 3 of the above former document provides for the special position of Islam. With regards to this, Shanmuga (2004) points out that the former Lord President of the Malaysian judiciary, Tun Mohamed Salleh Abas, 
had emphasized that Islam refers to "only acts as relate to rituals and ceremonies ...”. Further, another distinguished and the previous Lord President of the Malaysian judiciary, Tun Mohamed Suffian Hashim emphasized that “...Islam was made the official religion of this largely Muslim nation, primarily for ceremonial purposes, to enable prayers to be offered in the Islamic way on official public occasions, such as the installation or birthday of the Yang di-Pertuan Agong, Independence Day and similar occasions" (Soong, 2017: p. 123).

To ensure that Malaysia is seen by its diverse populace and the world at large as being a secular nation, Tunku Abdul Rahman, the "Bapa Malaysia"-the founding father of the nation, emphasized that the nation was formed as a secular State, with Islam as the official religion, as enshrined in the Constitution, in 1983. The third Prime Minister, Tun Hussein Onn echoed this cardinal "truth" clearly in the same year.

Shad Saleem Faruqi the nation's foremost constitutional academic as such, has emphasized, as in the spirit of the Federal Constitution, which this researcher opines is once too often forgotten by overzealous politicians and the heavily Malay-centric civil service that the constitutional provision on Islam does not derogate from any other provision of the Constitution [Article 3(4)]. This means, all rights are fully protected for non-Muslims and Muslims alike as provided by the Constitution, without diminution. Temporal authorities are given a higher public position than the religious-Syariah (Islamic laws) ones. The latter have their domains clearly delineated and have full authority on Muslim customs and family law. "The law of the land is enacted, expounded and administered by secular officials", going by the clear and historically nurtured social reality of the demographic plurality of Malaysia (Faruqi, 2012: p. 73).

The Rukun Negara, having been formulated by the then nation's highest governing authority itself-the National Consultative Council in 1970, attempted to clearly recognize the existential social reality that “... a nation of diverse races, religions and cultures... can be a source of strength" for the national polity (see Figure 1). This august document also clearly postulated in its preamble that,

We are dedicated to ensuring the existence and growth of a liberal society in which its members are free to practise and profess their own religions, customs and cultures consistent with the requirements of national unity. The Malaysian nation is indeed unique in having rich and diverse cultural traditions and practices. We aspire to a society in which this diversity can be an asset and a source of strength.

The principle, "Belief in God", in the Rukun Negara national philosophy can be characterised as an inappropriate and inconsiderate "requirement", for people who do not profess any established religious faith doctrines (Soong, 2017). These faiths do proclaim the belief in "God" as taught by their religious scriptures and doctrines.

It can be stressed that the above national philosophy statement is not a legal document. As it has been stated, it is the nation's document of the philosophy by which it is aspired that the people can strive to be united. Further, the above 


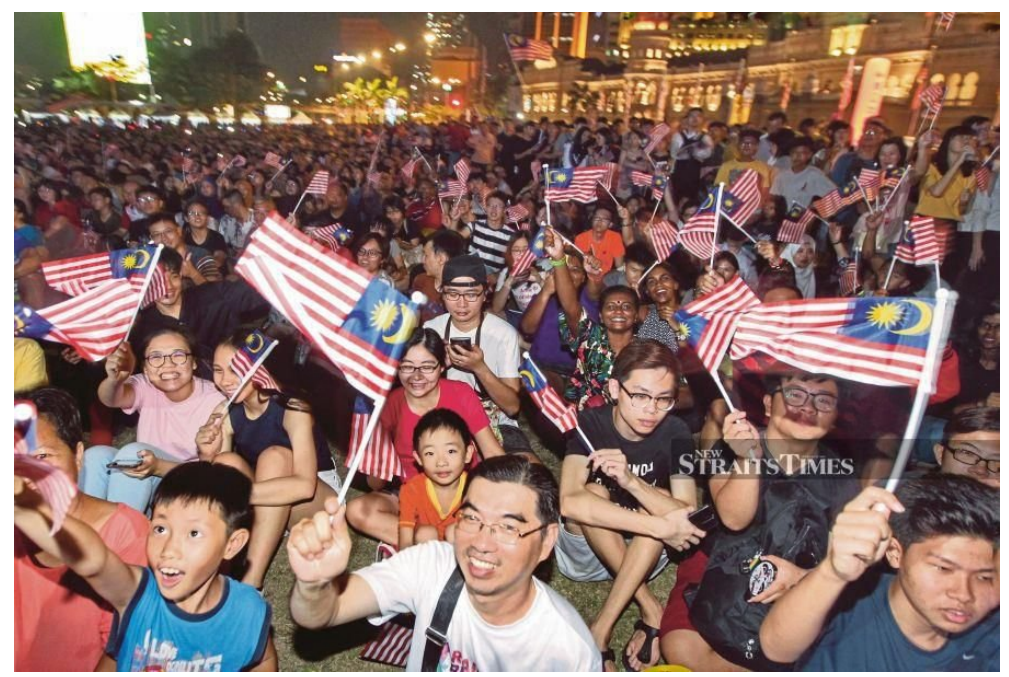

Figure 1. An Independence day celebration photo-take of young and old Malaysians from diverse backroumds "bonding" joyously.

principle "requires" and motivates the nation's citizens to be committedly moral, ethical and humanly-principled people who will live their lifes by the rule of law and human civility, contributing to one another's advancement and that of the nation. The issue of the minority languages and vernacular schools educational problematique (a subject of constant disagreement) in Malaya and then henceforth in Malaysia, were essential and crucial parts of the pre-Merdeka (Independence) social bargain. These and other aspects were deliberated and agreed upon by the representatives of the three major communities of Malaya, on the basis of the "social contract" grounded in the reality of a social-cultural pluralism seen as prevalent from pre-colonial times, and evolving since then.

As such, Article 152 (Section 2) Education Act 1996, provides that further in the secondary school levels too, Chinese (Mandarin) and Tamil languages can be taught with the request of at least of 15 parents.

Going back to the early days of our education system, we can see that the Barnes Report (Government of Malaya, 1951a: Article 18) had attempted to sow the seeds of loyalty in the then Malaya by declaring that a bilingualism foundational education curriculum with Malay and English as core language subjects, will constructively contribute to the evolution of national unity. Non-Malay parents were essentially encouraged to set aside their "vernacular attachments in the interests of a new social unity", and thereby "(they) have a right to be welcomed without reserve by the Malay people as fellow builders ( of national development and well-being) and fellow citizens" (Guan, 2009: p. 213).

This above position was however not accepted by later education reports 1952 Education Ordinance; [Government of Malaya (1951b)] [Fenn Wu Report] which advocated the retention of vernacular-Chinese education), which advocated a Malay medium national school system for the long run.

It can be seen that a far-reaching ramification of the above has witnessed the present, commonly observed social-political scenario of a rather ethnically mo- 
tivated and socially compartmentalized environment.

The colonial education system from the early twentieth century onwards had not attempted sufficiently comprehensively the process of a bonding national socialization, towards a Malayan nationhood (thenceforth flowing onwards to a Malaysian consciousness of a one nation), because the diverse communities were essentially schooled separately in Malay and vernacular schools. This was also very much structured as such owing to the geographically separated and alienated living conditions of the society.

It can thus be said that because there was no integrated, common educational ethos in the above divided education system, the spirit of a Malayan (Malaysian) nationalism and belonging was not strongly sown among the nation's population (Shanmugavelu et al., 2020).

\subsection{The National Education Philosophy}

However, the National Education Philosophy (1988) (NEP) had emphatically emphasized national unity in order for the nation to ascertain its progress forward. The essence of the FPK can be said to be as follows,

As education is universally recognised as an on-going effort towards developing the potential of individuals in a holistic and integrated manner, directed at producing citizens who are intellectually, spiritually, emotionally and physically balanced, knowledgeable, competent and able to live their lifes with high moral standards, and thereby contribute to the harmony and betterment of family, society and the nation at large.

The nation's education philosophy had clearly set the parameters as such, for the nation's crucial "apparatchiks"-functionaries (the civil servants, professionals, leader-politicians, citizens) to use education to realize and materialise the nation's continued progress, solidarity and the affirmation of national sovereignty.

\subsection{National Education Blueprint}

Of particular significance in this study are the topical eleven paradigm shifts of the 2013-2025 National Education Blueprint (2015), which are guided by the NEP above and the Razak Education Report of 1956, both of which have placed national unity as the nation's paramount goal. The Blueprint states clearly that the,

"education system should provide opportunities for pupils to share their experiences and aspirations in order to build and strengthen the foundations for unity among the people of Malaysia".

In line with the above mission for educational growth, Friedman (2016) quoting Seidman (2011), notes that in learning and acquiring knowledge, the ability to forge deep relationships, to cultivate deeper and better connections, that is, to love, to care, to hope, to trust, and thereby to build voluntary communities based on shared values, being man's unique human capacity as such, will certainly help 
BUILD and GROW a cohesive nation. It can be stressed here that this document focuses on the cardinal social value of transformation in its detailed plans. Competency in the national language-Bahasa Malaysia and English is a key paradigm shift emphatically laid out. This, it is aspired, will engender a strong sense of national identity for the continued cohesive progress and success of the nation (Muzaffar, 2017).

Further, the above document had given serious thought in its education components and substance, to enable learners to be accepting of one another as Malaysians. Ethnicity and religion are essentially subordinated here for the attainment of the nation's higher goal of a common national identity and national unity (Paradigm shift 3, national Education Blueprint 2013-2025).

This transformative shift strongly directs the curriculum, particularly for the subjects referred to as Islamic Education (Agama Islam) for Muslim students, and Moral Studies commonly for the non-Muslim learners, to help in the learning and practice of common universal values such as love, respect for all human beings, integrity, right as opposed to wrong, and justice.

However, although there is clearly an abundance of material and literature in all religious faiths on the above values, there is little that goes to show that these values are emphatically and concertedly "taught" in our Malaysian schools (ibid). This is as seen in the commonly observed social demarcations among Malaysian adults and youth. The education leaders, servant-politicians, parents, and teachers particularly, can be said to be accountable for this sad phenomenon in Malaysia today. The researcher and other "right-minded" citizens are of the view that this above state of affairs needs to be positively and comprehensively addressed, and this although we have in our possession the above well-crafted documents, such as our Federal Constitution, before undesired outcomes present themselves upon the Rakyat.

\subsection{The United Nations-APNIEVE's Vision of Education}

The United Nations (UN), UNESCO (United Nation Educational, Scientific, Cultural Organisation together with APNIEVE (Asia-Pacific Network for International Education and VALUES EDUCATION) in 1998 had proposed as one of the key pillars for twenty-first century education, the integration of contemporary and traditional humanistic VALUES, in national systems of education. The focus was clearly on the youth as future citizens of world nations, to “... be equipped with the knowledge, skills and ATTITUDES needed to live together in peace and harmony" (ibid p. iii). The learners are nurtured and "educated" to participate and co-operate with all others in school and co-curriculum activities. Schools of different streams can and need to get their students together for joint activities.

In today's times as such, the education authorities need to actively help parents to understand the long term benefits of the above programmes for the nation. Teacher education also has to be tuned in to the principles and signifiers of 
the above efforts. What is more, the crucial civil servants at all levels need to be shown why such simple and significant humanistic educational transformations are important for the nation's true progress.

However, the unpromising state of affairs today and of years past, of "politics in education, of constant political bickering in society, a rather detached and estranged state of relationships among the people which is not for the lack of a vision and desire for national solidarity and well-being in Malaysia. It can well be due to the lack of far-sightedness and maturity in present-day individuals-leaderspoliticians-civil servants, educationists-teachers generally and the growing youth, who can effect real change. This by all accounts, needs to change for the often strongly desired, united Malaysia.

The above state of affairs as studies appear to show, has also been compounded by the still retained, but in various forms nevertheless, even after the twenty year period set for the New Economic Policy-NEP, a Malay-Bumiputera bent in essentially all domains of Malaysian life (Mohamad, 2009).

A very recent development, which has been officially targeted to be implemented in the following year, is the banning of liquor in sundry shops, particularly those located fronting mosques, police stations (Wong, 2020. On the Beat Column, Sunday Star). It has been noted that this rather new and poorly envisioned regulation will most certainly affect the economic earnings and survival of Chinese businesses particularly, and the livelihood of others who have been engaged in this business for decades.

It is the stand of this researcher that the nation needs to undergo a paradigm shift, in going forward towards a much yearned-for cohesive Malaysian nation. The prevalent, crippling conflictual and ethnically-based partisan tendencies and practices, need to be subordinated to the nationhood principle and value that all citizens can attach themselves to, that is, a "Malaysia" as an idea and bonding, for an equal common coalescence and social amalgamation (Tan, 2020: p. 19).

The divisive and destructive strains of selfish partisan manipulations can then be gradually and surely be "expunged" to the pages of a past history.

A most recent illustration of the uphill battle more markedly pronounced today with regard to communal divisiveness fueled by the lowly character of present-day leaders, are the political developments in one state in the federation. Nazrin (2010), the state's ruler, stating that this was a failure of the peoples" aspirations - that of Malays, Orang Asli, Chinese, Indians, Muslims, Christians, Hindus, Buddhists and others of various faiths, clearly being all the creation of God, all experience the same challenges, have the same needs and hopes. $\mathrm{He}$ strongly warned, "...Do not mistreat the people due to the influence of vengeful emotions and close-minded political thinking" (NST 11.12.2010, p.3).

The above Royal's advice and warning is also relevant to and symptomatic of unhealthy developments in the nation as a whole. This is as based on the constant challenges to the legitimacy of the central government's hold on the reins of power, arising from the accusation that it is a "backdoor" government. The then former prime minister, Dr. Mahathir Mohamed and others, have often 
strongly challenged the Royal candidate above of his claimed majority support of parliamentarians (Leong \& Teoh, 2020, The Straits Times). Such political bickering that indicates a rabid and naked desire for position and power in the nation at a time when a destructive global pandemic-the COVID-19 is unrelentingly causing serious loss of life and ill health in our country, is thus seen as political self-centeredness.

A wanton disregard thus, for the noble, national aspirations of the national documents discussed hitherto, by poor leadership can lead the nation into dire straits. This form of leadership cannot therefore, be counted upon to build and strengthen the foundations for a united and resilient Malaysia.

Such leadership as discussed above, must be stridently censured, rehabilitated and if need be, removed completely. The nation's youth can then be shown "worthy torches" of men filling the places of the above, striving to blaze the way forward for a well-bonded and progressive society.

The often-highlighted and sensitively provocative stand that the vernacular school system is a primary cause of national disunity needs to be looked at more closely. The national government, particularly since 1970 onwards, has stridently and essentially short-sightedly, regardless of the social reality that the nation is a living pluralistic society for centuries, embarked on one-race directed programmes. Examples of this are the MARA (Majlis Amanah Rakyat-Council of Trust for the People, 1966) and other education one-race institutions, such as the Science schools (Hashim, 2019). Also, Muslim-Agamic schools, the Malay College Kuala Kangsar (MCKK), and Bumiputera economic-public service programmes, have been implemented now for decades. The goals are generally well lauded and recognized, that is, to uplift the particular Majority Malay-Bumiputera, indigenous community that has been left behind from colonial times.

However, with a diverse citizenry faced with the phenomenon and reality of depleting and limited resources, there needs to be real moderation and a "balance" in national policies, for the larger picture and the common good. This, despite, and the well-accepted constitutional provisions that we have [Articles $153,152,160(2), \ldots]$. We definitely do not want people, especially for the growing youth, to become disgruntled and engage in clandestine activities. There clearly therefore, needs to be open, constructive dialogue with national leaders, civil service and the RAKYAT, playing a positive role to unfailingly bring about all-embracing democratic and egalitarian (the cardinal and indisputable principle that all peoples are equal and should enjoy equal social, political and economic rights and opportunities) outcomes, to rightly benefit all Malaysians.

\subsection{Responses from Interviews with Students}

The vernacular school students, two from the upper primary Tamil stream and one from the upper primary Chinese, that the researcher interviewed showed that had sufficient mastery of the knowledge in the subjects involved in the interview questions.

Certain common and broad knowledge terminologies, such as "Photosynthe- 
sis" in Science in their native languages, were discussed. All the above students, exhibited the elements of the content involved generally well. However, none of them knew the Malay and English language terminologies and their spellings.

The candidates were also uncertain of the English term, "value". They had some knowledge of native-mother tongue versions of the above term. The Bahasa Malaysia terminologies for the above, and further, for "respect"-hormat, "polite"-sopan, "matter"-bahan, "belief"-percaya, "How are you?"-“Apa khabar?”, “energy"-“tenaga", "water cycle"-"saliran air", and other similar terms, were NOT in their repertoire of knowledge.

The above English language terms were also not within their grasp. The researcher attempted to use descriptions for the terms, in Tamil and Malay to help the students understand the cognitive "knowledge" of the terminologies.

Their proficiency skills and confidence in Malay and English was weak. These upper primary students will soon enter secondary schools where the above two languages are core subjects. The national language-Bahasa Malaysia, is the official medium of instruction at the above level of education. It can well be expected, as also reports indicate, these students can fall behind in their educational progress, at the secondary and further, at the tertiary levels of education (Sua \& See, 2016; Wong, 2017).

In line with the theme of this paper thus, these students can fall back to their own native languages as much as they need to, and the common identity aspired by the application of the one national language-Bahasa Malaysia, together with English language as the international language of knowledge and communication, may well fall short.

The urgent and committed need to apply the national language in all streams of Malaysian education, as the primary medium of instruction and communication, is paramount today. The teaching and learning of English, Chinese and Tamil languages in the schools, particularly the vernacular schools, need to be continued conscientiously.

In the above vernacular schools, the ethnic-cultural literature subjects as additional curriculum subjects, that is, apart from the native language subjects being already taught-Chinese and Tamil, can further be taught in the above native languages.

The rest of the school curriculum needs to be conducted in the national language.

\subsection{Finland-Multicultural-Multilingual Education-Embracing Diversity, Enhancing Quality}

Some lessons can well be learnt by Malaysian education authorities and educators from the well-regarded Finnish education system.

Education in Finland, since 2014 particularly, with the admission of migrants from culturally diverse nations, diversity is no longer seen as a dislocating force. The concepts "multicultural", "multilingual" and "pluralistic" are used commonly 
with reference to the school as well as the society. The Finnish students' identities today are described as multicultural.

As the Finnish national curriculum document states,

"The school as a learning community is part of a culturally transforming and pluralist society where the local and the global overlap. Different identities, languages, religions and beliefs coexist and interact" (NCC (National Core Curriculum), 2014, as in Zilliacus et al., 2017).

[(Emphasis by researcher). (Taking steps towards institutionalising multicultural education-The national curriculum of Finland Harriet Zilliacus, Gunilla Holm \& Fritjof Sahlström, Multicultural Education Review, 2011-Issue 4, published online 2 Oct 2017)].

As Robinson (2015) observes, “... all Finnish schools are required to follow a broad and balanced curriculum". This curriculum is made up of the arts, sciences, mathematics, languages, and physical education. An educator and the education system as well, needs to necessarily be cognizant three epistemological forms of courses of deliberative action:

1) A critique of the way thing are,

2) A vision of how they should be, and

3) A well and holistically thought-out theory of change for the desired (pp. 60, $\mathrm{xvi)}$.

The education miracle in Finland often lauded by people around the world, is essentially due to the encouragement the schools themselves are given to have close links with their lived communities, and the learners' parents and their other family members. Further, no standardised testing is conducted except a final examination at the end of high school.

With the goal of educational transformation emphasing community interaction and acceptance, it can be observed that Finland is well on its national trajectory of evolving and cultivating learners who understand the world around them becoming "fulfilled individuals and active, compassionate citizens" (ibid p. $\mathrm{xvi)}$.

This, it can be noted thus, appears to be the Finnish pathway towards multiculturalism comingled with the existent multilingualism elements, in the everyday life of the nation. The enabling and driving force for the above has been the official stand of the government that cultural and linguistic diversity and different worldviews constitute an innate richness and a positive resource (op cit).

\subsection{Singapore-Ascribing Official Status and Appropriacy to Multi-Lingual Education}

Singapore, like Malaysia has Malay (Bahasa Melayu) as its official national language since its independence. The status of Malay is not subject to any threat of abolition or disregard in any form whatsoever. The nation feels it is for its best interests, in the geo-political perspective primarily, to ascribe Malay the "crown" status as it was also the national language of Malaysia and Indonesia. This is de- 
spite that the Malay population is an ethnic minority.

With language planning and policy implementation being highly centralized, which enables a well-controlled top-down approach and decision-making, the English language was made an official language, and as the main medium of instruction. The nation's official documents explain the reason for this as that, for pragmatic reasons, English functioning extensively as the global language of technology and economics, will vigorously help Singapore move along with the tide of world socio-economic development.

English has further been accorded official first language status in education. The other minority languages-Malay, Chinese (Mandarin) and Tamil, although co-official languages with English (Singapore Independence Act 1965), are regarded as second-language-status subjects. These latter languages are encouraged and allowed to be taught in and as language and literature subjects.

The primary curriculum courses-arts, sciences, mathematics, computing, physical education, electronics, history, humanities and so on, are taught in English. The vernacular languages are used in the learning of the mother tongue language, and for the ethnic literatures. English is overarchingly applied as a neutral, common and knowledge-providing language, historically and internationally well-placed for general communication, and as the primary national tool

\section{for bridging cultural differences.}

The nation's vision for national integration and solidarity is thus well embedded in this educational scheme with Malay as the national language, English as the nation's national tool for bringing the diverse peoples, especially the young, together through the extensive multi-subject school curriculum, and the study of mother tongue languages and literatures thereby providing strong cultural roots and values and "...enabl(ing) them to understand what makes us what we are today” (Tan, 1986 quoting Minister of Education, Tony Tan Keng Yam, in Siemund \& Li, 2020).

\section{Implications and Conclusions}

- The nation's citizenry, in the view of this researcher, has sufficiently imbibed a yearning to belong to the nation. This is as noted that the multi-ethnic multicultural communities have lived in a state of independence and relative external peace, for over half a century. New generations of Malaysians have now come to be born in the land as Malaysian citizens.

- It can be strongly noted that Malaysia being a multi-cultural society, has not witnessed and borne the pains of inter-ethnic strife, except the 1969 riots. This is as contrasted with many countries-developing and even so-called developed ones. The peoples' ability and a sense of magnanimity to live in healthy neighbourliness and understanding, if not acceptance, is a strong national asset that can be further built upon.

- The overarching economic and socio-political policies have to be structured such that the nation's citizenry can ALWAYS be empowered with the sense 
of a Malaysianness.

- $\operatorname{Razak}$ (2021: p. 13) emphasizes that it is urgently required that a holistic framework involving an education "scenario planning", be developed. This can be designed in line with the United Nations Sustainable Development Goals (SDGS) Education 2030 framework. Goal four of the SDGs states that inclusive and quality education can bring about the "WORLD THAT WE WANT, ONE THAT PROJECTS AN EQUITABLE AND JUST ECOSYSTEM FOR ALL" (ibid).

- The above visionary and pragmatic stand ties in congruently with our $\mathrm{Na}$ tional Educational Philosophy's advocation of the all-embracing national aspiration of "Sejahtera" and "Kesejahteraan diri" (individual well-being). Learners are to be holistically educated towards the evolution of a balanced and harmonious citizenry, in solidarity. The instruments need then to be a good foundation in the nation's National Language, English, one's own cultural languages, and competence in knowledge areas for meaningful and robust national progress.

- In order to get back on track and acknowledging that Malaysia is allowing itself to be incrementally "drained", even if it is assumed to be a minimally occurring phenomenon, and together with the fact that we are living with a fractured education system as discussed earlier, it is thus imperative for the future well-being of the nation that sustainable socio-economic goals are actively seen to be implemented equitably. The Asian Development Bank and the United Nations Development Programme (Galimberti, 2010: p. 12, NST) has emphasized the removal of systemic barriers, and national efforts for committed investment in institutional and public readiness to change and shift to a new and inclusive paradigm platform, going forward in the $21^{\text {st }}$ century, and farther.

- Congruently, as with language education that needs appropriate transformation as discussed above, and this while "living the spirit" of cultural diversity in the context of "multi-ethnicism", so too does religious education need to come fully under the ambit of the National Constitution and the governance of the ruling government. Religious schools therefore need to teach their students the national language, Bahasa Melayu and English more actively, these being the nation's official languages. Nationhood values as based on the Rukun Negara, can be strongly "grounded" in students through the learning of these above languages (Naidu, 2017).

- The time has clearly come in this $21^{\text {st }}$ century "global village", that students in these and other "one-race" institutions particularly (there is a sprinkling of non-Malay-Bumiputera students in the above), be guided to take proactive efforts to become more proficient in these core Malaysian languages-Malay and English, apart from acquiring their intended curriculum-subjects' knowledge and skills. The need for allowing any external forms into all sections of Malaysian society, such as "Arabisation" and so on, need to be broadly thought 
out, for multi-cultural Malaysia to move forward "on its own merits". Much can be drawn from the life values of the Orang Asli, Malays, Chinese, Indians and the natives of Sabah and Sarawak constituting the peoples of the land, thereby throwing light on an invaluable and a vast richness, engraving a unique niche and a forte among global citizens that all Malaysians can always be proud of. We need to explore and delve deeper into our own histories and the existent vibrant Malaysian social mosaic for a meaningful appreciation and clarity per humankind, and thence be content to live and strive on, in its simple and constructive goodness.

- As it is often lamented that an ill-founded focus on physical-material-economic development has ravaged the world and continues to do so, it is clear today that a HUMANISTIC-material-ecological balance, for the common good can be striven for. Pockets of inter-communal conflicts and cruel strive are glaringly present today. This needs to be eradicated completely from the lives of humankind, and this is possible by appropriate social-ecological and balanced education. This has to be in strict accord to the three pillars of sustainability-economic, environmental, and SOCIAL. (Circular, https://www.circularecology.com/sustainability-and-sustainable-development. html). With committed effort this above goal is well within our reach, before matters become untenable, especially with the constantly mushrooming genre of individuals who seek only political glory and personal profit.

- The models of "progressive" nations and their inclusive educational practices discussed above can be adapted and applied here. The Scandinavian nations, Singapore and other Asian nations such as Vietnam and China have often ranked high in the PISA (Programme for International Student Assessmentupper primary level assessments in Mathematics, Reading, Science) ratings. This can well go to indicate that the curriculum content and teaching-learning strategies employed in these nations have borne better and rewarding fruit, in that the well-devised and positive character and substance of the educational materials presented to learners, it can be noted, have been imbibed by these learners. This is so as their performances in the PISA assessments have been most consistent, year in and year out. Malaysia can attempt to learn some good lessons from these nations.

- A nation lacking a palpable and profound foundation in the humanities that resonates with its history and the living cultures of its citizens will therefore then need to constantly "keep looking over its shoulders". An integrated education programme engaging courageously the nation's history, linguisticcultural attributes (which can include and promote moral-religious values), Science and Technology, Social Studies and Economics, at all levels can help strengthen the nation's social-psychological psyche and foundation and propel it forward to great heights.

- As Gardner (2006) contends, there needs to be a synthesis and synergy that together with and beyond specialization training, a nation's education sche- 
ma can strive to humanise the disparate academic disciplines and also the marked social orientations of a plural society, towards a functional composite whole. This then orientates the nation's education programme to be relevant and competitive for the real world today. Examples of this are seen in the Japanese, Chinese, Indian and other culture-based nations, that have not sidelined their core traditions, and yet have "progressed" tremendously.

- As such, vernacular school educationists in Malaysia need to unfailingly bear in mind, that they cannot be too assertive as regards their linguistic rights. It must necessarily be borne in mind that Malay nationalists would then construe their actions as a challenge to the constitutionally mandated and supreme position of the national language. The national language has to be seen as necessarily a common binding force in education that can help build multicultural-national citizens and a one Malaysian identity. The vernacular school students were expected to become "Malay-knowing bilinguals". The vernacular educationists need to clearly understand that in this heterogeneous multi-ethnic nation, that all Malaysian citizenry can undergo mother tongue bilingual education as a transitional phase, and thenceforth in the national language in the secondary stream. Their school "products" can then be enabled to imbibe a sense of belonging and national unity (Tan, 1986; Ozog, 1963 in above, pp. 75-76).

- It is time that these communities on their part, play their constructive roles as constituent elements and pillars of the national citizenry, working in unison and constructive dialogue with state institutions, such as Parliament, state legislatures, the courts, the police force and so forth, as their instrumental identity references. The state, on its part needs to concertedly, as discussed above, empower these citizens to experience the substance (Ratnam, 2019: p. 42) of equitable socio-economic benefits, as for the Malay-Bumiputera and native communities.

- The existent fractured education system which is silently and almost surreptitiously marching on, questionably forward, or regressively, can partake of the vast education infrastructure, particularly the localised administration organisations (district education departments throughout the nation) today, to actively enable the training of the teachers, school heads and students in the broad and extensive implementation of the National Language and English language curriculum in all Malaysian education institutions. The cultivation and inculcation of nationhood values directed towards the deepening of the sense of belonging and solidarity in Malaysian youth and society, contributing to the evolution of the Malaysian identity, needs to be the daily working call of these education institutions.

- The bridges for the bonding of the Malaysian peoples "without malice toward none and charity to all", need to be (re)built and strengthened. The questions always linger on, "Are we doing enough? Can we do better?" This above then, is the "path for the day after, and after" for the multicultural Malaysian nation. 


\section{Conflicts of Interest}

The authors declare no conflicts of interest regarding the publication of this paper.

\section{References}

(2013). 2013-2025 National Education Blueprint (Preschool to Secondary Education). Putrajaya: Kementerian Pendidikan Malaysia.

(2013). The New Economic Policy and Poverty at the Margins: Family Dislocation, Dispossession and Dystopia in Kelantan. In E. T. Gomez, \& J. Saravanamuttu (Eds.), The New Economic Policy in Malaysia-Affirmative Action, Ethnic Inequalities and Social Justice. Singapore: National University of Singapore Press.

Act 550 Education Act 1996 (2012). Laws of Malaysia. The Commissioner of Law Revision.

Circular. Ecology-Making a Difference Together. Sustainability and Sustainable Development-What Is Sustainability and What Is Sustainable Development? https://www.circularecology.com/sustainability-and-sustainable-development.html

Faruqi, S. S. (2012). The Bedrock of Our Nation: Our Constitution. Kuala Lumpur: Zubedy Ideahouse Sdn Bhd.

Federal Constitution 1957 (2010). The Commissioner of Law Revision, Malaysia.

Friedman, T. L. (2016). Thankyou for Being Late-An Optimist's Guide to Thriving in the Age of Accelerations. United Kingdom: Penguin Random House.

Furnivall, J. S. (1948). Colonial Policy and Practice: A Comparative Study of Burma. Cambridge: Cambridge University Press.

Galimberti, S. (2010) Youth Must Get Out from Comfort Zone to Rethink Public Policies. New Straits Times, 28.10.2010, 12.

Gardner, H. (2006). Five Minds for the Future. Boston, MA: Harvard Business School Press.

Government of Malaya (1951a). Report of the Committee on Malay Education, Federation of Malaya [Barnes Report]. Kuala Lumpur: Government Publication.

Government of Malaya (1951b). Chinese Schools and the Education of Chinese Malayans[Fenn Wu Report]. Kuala Lumpur: Government Publication.

Guan, L. H., as in Lim, T. G. et al. (2009). Multiethnic Malaysia. Petaling Jaya: Strategic Information and Research Development Centre.

Hashim, N. (2019) Racism in the Framework of Malaysia's Education System. World News, 22 August 2019.

Leong, T., \& Teoh, S. (2020) Malaysia's Muhyiddin Named PM. The Straits Times Asia, 1.3.2020

Majid, M. (2021) Searching for a Statesman-Thinking Malaysia with Biden as US President. New Straits Times, 25 January 2021.

Mohamad, M. (2009). Politics of the NEP and Ethnic Relations in Malaysia. In T. G. Lim, A. Gomez, \& R. Azly (Eds.), Multiethnic Malaysia: Past, Present and Future (pp. 113140). Petaling Jaya: Strategic Information and Research Development Centre and MIDAS, UCSI.

Muzaffar, C. (2017). Reflections on Malaysian Unity and other Challenges. Kuala Lumpur: Zubedy Ideahouse Sdn Bhd.

Muzaffar, C. (2017). Reflections on Malaysian Unity and other Challenges. Kuala Lum- 
pur: Zubedy Ideahouse Sdn Bhd

Naidu, S. (2017). The National Integration Trajectory towards National Development: The Inculcation Dynamics of English Language Nationhood Values Education in Malaysian Secondary Schools. PhD Thesis, Kubang Pasu District: Universiti Utara Malaysia.

Nazrin, R. (2010) Not Something to be Proud of, Sultan Nazrin Slams Politicians Amidst State Crisis. Zahratulhayat Mat Arif, NST 11.12.2010, 3.

NCC (2014). Curriculum in Finland. Helsinki: Finnish National Board of Education.

Ozog, A. C. K. (1963). Bilingualism and National Development in Malaysia. Journal of Multicultural and Multilingual Development, 14, 59-72. https://doi.org/10.1080/01434632.1993.9994520

Portal Maklumat Pendidikan Islam (n.d.). https://simpeni.islam.gov.my/

Quick Facts 2019 Malaysia Education. https://www.moe.gov.my/

Ratnam, K. J. (Professor) (2019). Identity, Nationhood and State-Building in Malaysia. Petaling Jaya: Strategic Information and Research Development Centre (SIRD).

Razak, D. A. (2021). Foresighting Higher Education Holistically. New Straits Times.

Robinson, K. (2015). Creative Schools. Great Britain: Allen Lane.

Seidman, D. (2011). How: Why We Do Anything Everything. Dublin, OH; Hoboken, NJ: Online Computer Library Center, John Wiley \& Sons.

Shanmuga, K. (2004). Islam Not Malaysia’s Official Religion. Malaysiakini.

Shanmugavelu, G. Parasuraman, B., Arokiasamy, R., Kannan, B., \& Vadivelu, M. (2020). The Role of Teachers in Reflective Teaching in the Classroom. Shanlax International Journal of Education, 8, 30-33. https://doi.org/10.34293/education.v8i3.2439

Siemund, P., \& Li, L. J. (2020) Multilingualism and Language Policy in Singapore. In H. Klöter, \& M. S. Saarela (Eds.), Language Diversity in the Sinophone World (pp. 205228). London: Routledge.

Soong, K. K. (2017). Malaysia's 14th General Election-The Big Issues. Petaling Jaya: Suara Initiatif Sdn Bhd.

Sua, T. Y., \& See, T. H. (2016). The Chinese Language Movement in Malaysia, 19521967-Language, Ethnicity and Nation-Building in a Plural Society. Petaling Jaya: Strategic Information and Research Development Centre (SIRD).

Tan, K. Y. (1986). Quoting Minister of Education.

Tan, N. (2020) Partisan Gravity. The Star, 29 January 2020, 19.

United Nations (UN), UNESCO (United Nation Educational, Scientific, Cultural Organisation) together with APNIEVE (Asia-Pacific Network for International Education and VALUES Education) (1998). Learning to Live Together in Peace and Harmony. Bangkok: UNESCO Principal Office for Asia and the Pacific.

Wong, C. W., \& DBKL (City Council of Kuala Lumpur) (2020) Act Leaves behind Bitter Taste. 29.11.2020. On the Beat Column, Sunday Star.

Wong, V. (2017). The Language Medium Policies: A Study on the Development of Independent Chinese Secondary Schools (ICSS) in Malaysia. KATHA, 13, 32-53. https://doi.org/10.22452/KATHA.vol13no1.2

Yesuiah, S. (2020) The Case for Vernacular Schools. The Star.

Zilliacus, H., Holm, G., \& Sahlström, F. (2017). Taking Steps towards Institutionalising Multicultural Education-The National Curriculum of Finland. Multicultural Education Review, 9, 231-248. https://doi.org/10.1080/2005615X.2017.1383810 


\section{Note}

Some knowledge concepts and subject terminologies discussed with students

Photosynthesis, "Fotosintesis",

Matter, Knowledge, Current, "Arus letrik",

Recycle, Water cycle, Polite, Respect, How are you?, “Apa khabar?”,

Value, "Nilai",

Belief, "Kepercayaan",

Energy, Vaccine, "Vaskin",

Metamorphosis, "Perubahan"

Change, Cell, Technology, “Teknologi”,

Crops, Agriculture, Food, Oxygen, Carbon Dioxide, Plants, "Where are you from?", "I am well", "How do you do?",

Teenager, "Remaja”. 